\title{
Validation of topochemical models for the prediction of permeability through the blood-brain barrier
}

HARISH DUREJA

ANIL KUMAR MADAN*

Faculty of Pharmaceutical Sciences

M. D. University, Rohtak-124001, India
Accepted September 7, 2007
Recently published topochemical models for permeability through the blood-brain barrier were validated and cross-validated in the present study. Five models based on three topochemical indices, Wiener's topochemical index - a distance-based topochemical descriptor, molecular connectivity topochemical index - an adjacency-based topochemical descriptor and eccentric connectivity topochemical index - an adjacency-cum-distance based topochemical descriptor, for permeability of structurally and chemically diverse molecules through blood-brain barrier were used in the present investigation. A data set comprising 62 structurally and chemically diverse compounds was selected. This data set was divided into two sets of 31 compounds each - one to serve as the validation set and other as the cross-validation set. The values of all the three-topochemical indices in the original as well as in the normalized form for each of the 31 compounds of the validation set were computed using an in-house computer program. Resultant data was analyzed and each compound was assigned a permeability characteristic using topochemical models, which was then compared with the reported permeability through the blood-brain barrier. Accuracy of prediction of these models was calculated. The same procedure was similarly followed for the crossvalidation set. Studies revealed accuracy of prediction of the order of $70-80 \%$ during validation. Surprisingly, very high predictability of the order of 77-91\% was observed during cross-validation. High predictability observed during validation as well as cross-validation authenticates topochemical models for prediction of permeability through the blood-brain barrier.

Keywords: topochemical indices, Wiener's topochemical index, molecular connectivity topochemical index, eccentric connectivity topochemical index, permeability, blood-brain barrier

\footnotetext{
*Correspondence, e-mail: madan_ak@yahoo.com
} 
An important aspect of drug design is the consideration of the potential for penetration of the blood-brain barrier by a new candidate drug molecule (1). There has been a surge in computational efforts to compute absorption, distribution, metabolism, excretion, and toxicity properties, including blood-brain barrier (BBB) partitioning, of structurally diverse compounds, including drugs (2-5). A good example of the great utility of a predictive computational model in drug discovery is the model for predicting BBB penetration (6). Prediction of passage across the BBB is of importance for centrally acting drugs or peripherally acting drugs, which should be devoid of CNS side effects (7). The BBB is a selective barrier formed by the endothelial cells that line cerebral microvessels. It acts as a physical barrier because complex tight junctions between adjacent endothelial cells force most molecular traffic to take a transcellular route across the BBB, rather than moving paracellularly through the junctions, like in most endothelia (8). Modeling blood-brain portioning is a challenging problem both because of the paucity of data and the task of establishing a useful relation between the molecular structure and measured blood-brain partitioning (1). Experimental determination of brain-blood partitioning is time-consuming, difficult and expensive (9). A broadly applicable method for predicting the BBB permeation of candidates at an early stage of discovery would have a great impact on drug research and development (10).

Physicochemical properties and biological activities of organic compounds change in a very systematic way with changes in chemical structure (11). Topological indices have been successfully employed in developing a suitable correlation between chemical structure and biological activity by translating chemical structures into numerical descriptors (12). Topostructural and topochemical indices fall into the category normally grouped together as topological indices. Topostructural indices are topological indices that encode information about the adjacency and distance of atoms in molecular structures, irrespective of the chemical nature of the atoms involved in bonding or factors such as hybridization states and the number of core/valence electrons in individual atoms. Topochemical indices are parameters that quantify information about the topology (connectivity of atoms), as well as specific chemical properties of the atoms making a molecule (13).

The objective of the present study is to validate the recently published topochemical models (14) for the prediction of permeability through the blood-brain barrier using external validation and cross-validation sets. Validation and cross-validation of the topochemical models based on Wiener's topochemical index, molecular connectivity topochemical index and eccentric connectivity topochemical index in the original and their normalized forms for permeability through the blood-brain barrier have been investigated.

\section{EXPERIMENTAL}

\section{Calculations of topochemical indices}

Wiener's topochemical index $\left(\mathrm{W}_{\mathrm{c}}\right)(15)$ is a modified form of the oldest and most widely used distance based topological index - Wiener's index (16) and this modified 
index takes into consideration the presence as well as relative position of heteroatoms in a molecular structure. It is defined as the sum of chemical distances between all the pairs of vertices in a hydrogen suppressed molecular graph, i.e.:

$$
\mathrm{W}_{\mathrm{c}}=\frac{1}{2} \sum_{i=1}^{n} \sum_{j=1}^{n} P_{i_{c} j_{c}}
$$

where $P_{i_{c} j_{c}}$ is the chemical length of the path containing the smallest number of edges between vertex $i$ and $j$ in graph $G, n$ is the maximum possible number of $i$ and $j$.

The normalized Wiener topochemical index $\left(n \mathrm{~W}_{\mathrm{c}}\right)$ values were calculated as the ratio of Wiener's topochemical index value to the total number of vertices in a hydrogen suppressed molecular graph.

Molecular connectivity topochemical index $\left(\chi^{\mathrm{A}}\right)(17,18)$ is defined as the summation of the modified bond values of adjacent vertices for all the edges in the hydrogen suppressed molecular graph according to the following equation:

$$
\chi^{A}=\sum_{i=1}^{n}\left(V_{i}^{c} V_{j}^{c}\right)^{-1 / 2}
$$

where $n$ is the number of vertices, $V_{i}^{c}$ and $V_{j}^{c}$ are modified degrees of adjacent vertices $i$ and $j$ forming the edge $\{i, j\}$ in a graph $G$. This is a modified form of one of the most widely used adjacency based topological indices - molecular connectivity index (19) and it takes into consideration the presence as well as relative position of heteroatom(s) in a molecular structure.

The normalized molecular connectivity topochemical index $\left(n \chi^{\mathrm{A}}\right)$ was calculated as the ratio of the molecular connectivity topochemical index value to that of the total number of vertices in a hydrogen suppressed molecular graph.

The eccentric connectivity topochemical index $\left(\xi_{c}^{c}\right)(20)$ is a modified form of an adjacency-cum-distance based topological index - eccentric connectivity index (21) and this modified index takes into consideration the presence as well as relative position of the heteroatom(s) in a molecular structure. The eccentric connectivity topochemical index is defined as the summation of the product of chemical eccentricity and the chemical degree of each vertex in the hydrogen suppressed molecular graph having $n$ vertices, that is:

$$
\xi_{c}^{c}=\sum_{i=1}^{n}\left(E_{i c} V_{i c}\right)
$$

where $V_{i c}$ is the chemical degree of vertex $i, E_{i c}$ is the chemical eccentricity of vertex $i$ and $n$ is the number of vertices in graph $G$.

The normalized eccentric connectivity topochemical index $\left(n \xi_{c}^{c}\right)$ was calculated as the ratio of the eccentric connectivity topochemical index value to that of the total number of vertices in a hydrogen suppressed molecular graph.

The authors made an attempt at a simpler approach to predict the permeability through BBB of diverse series of compounds using topochemical models. These reported 
H. Dureja and A. K. Madan: Validation of topochemical models for the prediction of permeability through the blood-brain barrier, Acta Pharm. 57 (2007) 451-467.

Table I. Topochemical models derived from a training set of 28 chemically and structurally diverse compounds (14)

\begin{tabular}{|c|c|c|c|}
\hline Index & Range in the model & Index value & $\begin{array}{l}\text { Overall accuracy } \\
\text { of prediction (\%) }\end{array}$ \\
\hline $\begin{array}{l}\text { Wiener's topochemical } \\
\text { index }\left(W_{c}\right)\end{array}$ & $\begin{array}{l}\text { Permeable } \\
\text { Transitional } \\
\text { Impermeable }\end{array}$ & $\begin{array}{c}\leq 910.056 \\
>910.056-<3004.191 \\
\geq 3004.191\end{array}$ & 93.8 \\
\hline $\begin{array}{l}\text { Normalized Wiener's } \\
\text { topochemical index }\left(\mathrm{nW}_{\mathrm{c}}\right)\end{array}$ & $\begin{array}{l}\text { Permeable } \\
\text { Transitional } \\
\text { Impermeable }\end{array}$ & $\begin{array}{c}\leq 49.04 \\
>49.04-<92.27 \\
\geq 92.27\end{array}$ & 94.7 \\
\hline $\begin{array}{l}\text { Molecular connectivity } \\
\text { topochemical index }\left(\chi^{\mathrm{A}}\right)\end{array}$ & $\begin{array}{l}\text { Permeable } \\
\text { Transitional } \\
\text { Impermeable }\end{array}$ & $\begin{array}{c}\leq 12.086 \\
>12.086-<13.744 \\
\geq 13.744\end{array}$ & 83.3 \\
\hline $\begin{array}{l}\text { Eccentric connectivity } \\
\text { topochemical index }\left(\xi_{c}^{c}\right)\end{array}$ & $\begin{array}{l}\text { Permeable } \\
\text { Transitional } \\
\text { Impermeable }\end{array}$ & $\begin{array}{c}\leq 404.227 \\
>404.227-<1032.901 \\
\geq 1032.901\end{array}$ & 94.1 \\
\hline $\begin{array}{l}\text { Normalized eccentric } \\
\text { connectivity topochemical } \\
\text { index }\left(n \xi_{c}^{c}\right)\end{array}$ & $\begin{array}{l}\text { Permeable } \\
\text { Transitional } \\
\text { Impermeable }\end{array}$ & $\begin{array}{c}\leq 19.249 \\
>19.249-<31.949 \\
\geq 31.949\end{array}$ & 88.9 \\
\hline
\end{tabular}

topochemical models (Table I) were developed using a training set of 28 structurally and chemically different compounds with established CNS permeation tendency, having the predictability from 83 to $95 \%$ (14). The aforementioned topochemical models were validated by an external test set of 31 compounds and cross-validated using another external test set of 31 chemically and structurally diverse compounds.

A reliable and predictive model should be statistically significant and robust, provide accurate prediction for an external dataset not used during model development and have its application boundaries defined. Iyer et al. (22) have reported a BBB study on a training set of 56 structurally and chemically diverse molecules and 7 molecules for the test set. The authors have omitted one molecule (methane) from this data set for lack of sufficient computed properties and used the remaining 55 compounds of training set and 7 compounds of the test set. These 62 compounds were divided into two sets. Compounds having an odd serial number were designated as the test or validation set and those having an even number were separated as the cross-validation set. The 31 compounds for validation set are listed in Table II and 31 compounds for the cross-validation set are listed in Table III.

The values of Wiener's topochemical index/normalized Wiener's topochemical index were computed for each compound using an in-house computer program. Subsequently, characteristic permeability was assigned to each compound using the reported models (14), which was then compared with the reported permeability (22). Permeability was reported quantitatively as $\log \mathrm{BB}$ value. The compounds possessing log BB values of $\leq-0.3$ were considered to be permeable and compounds possessing log BB values of $>-0.3$ were considered to be impermeable for the purpose of the present study. Vari- 
H. Dureja and A. K. Madan: Validation of topochemical models for the prediction of permeability through the blood-brain barrier, Acta Pharm. 57 (2007) 451-467.

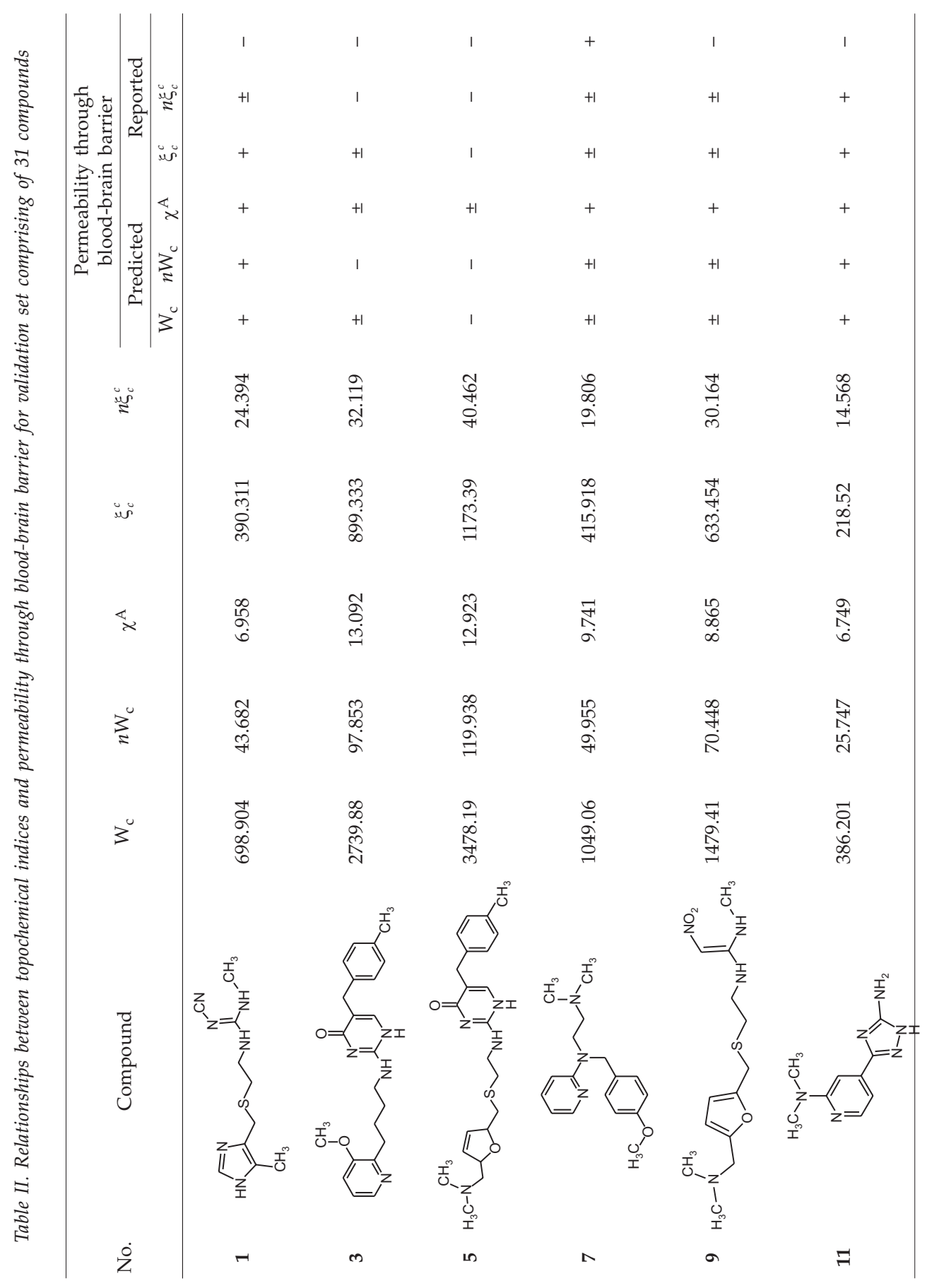


H. Dureja and A. K. Madan: Validation of topochemical models for the prediction of permeability through the blood-brain barrier, Acta Pharm. 57 (2007) 451-467.

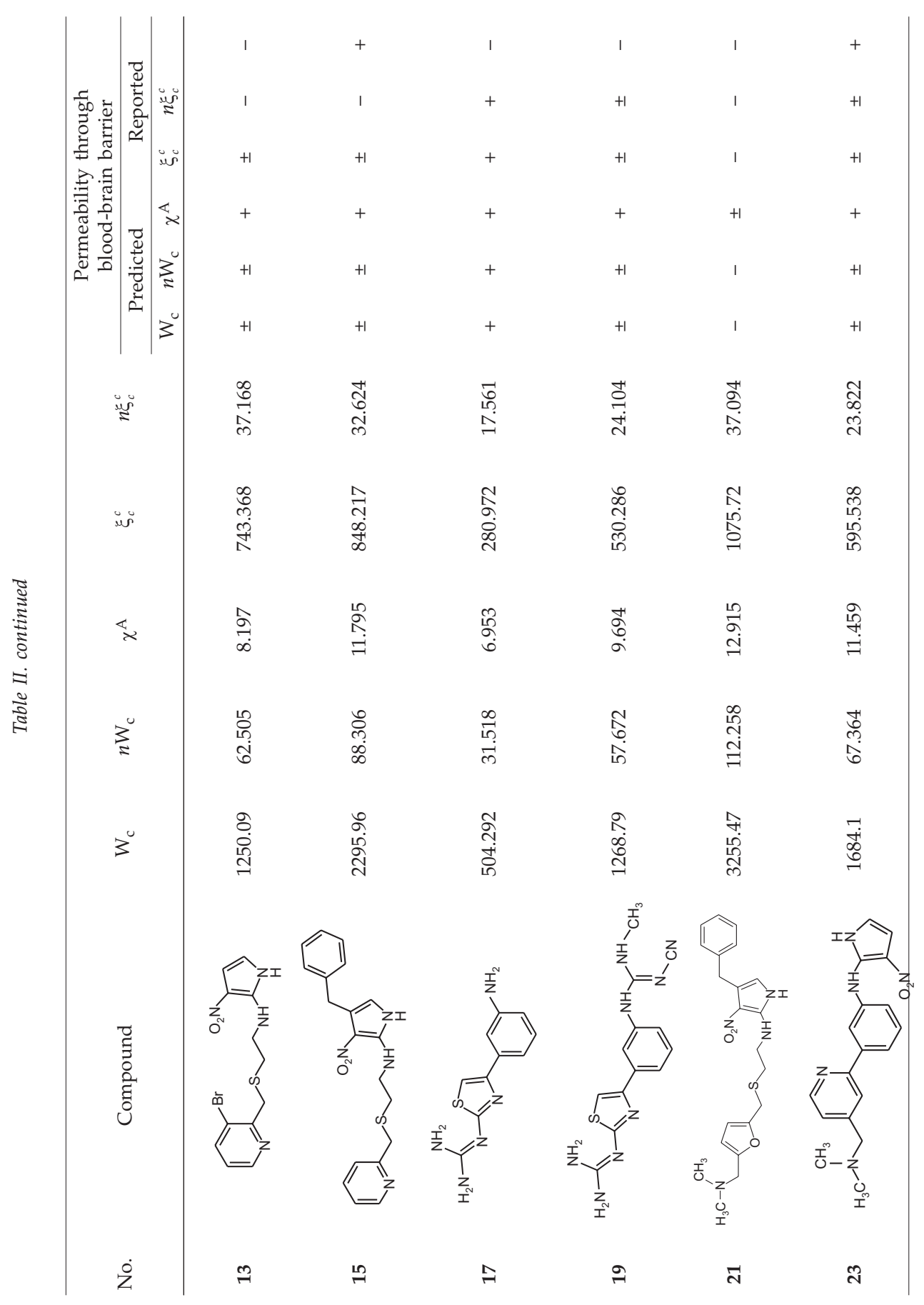


H. Dureja and A. K. Madan: Validation of topochemical models for the prediction of permeability through the blood-brain barrier, Acta Pharm. 57 (2007) 451-467.

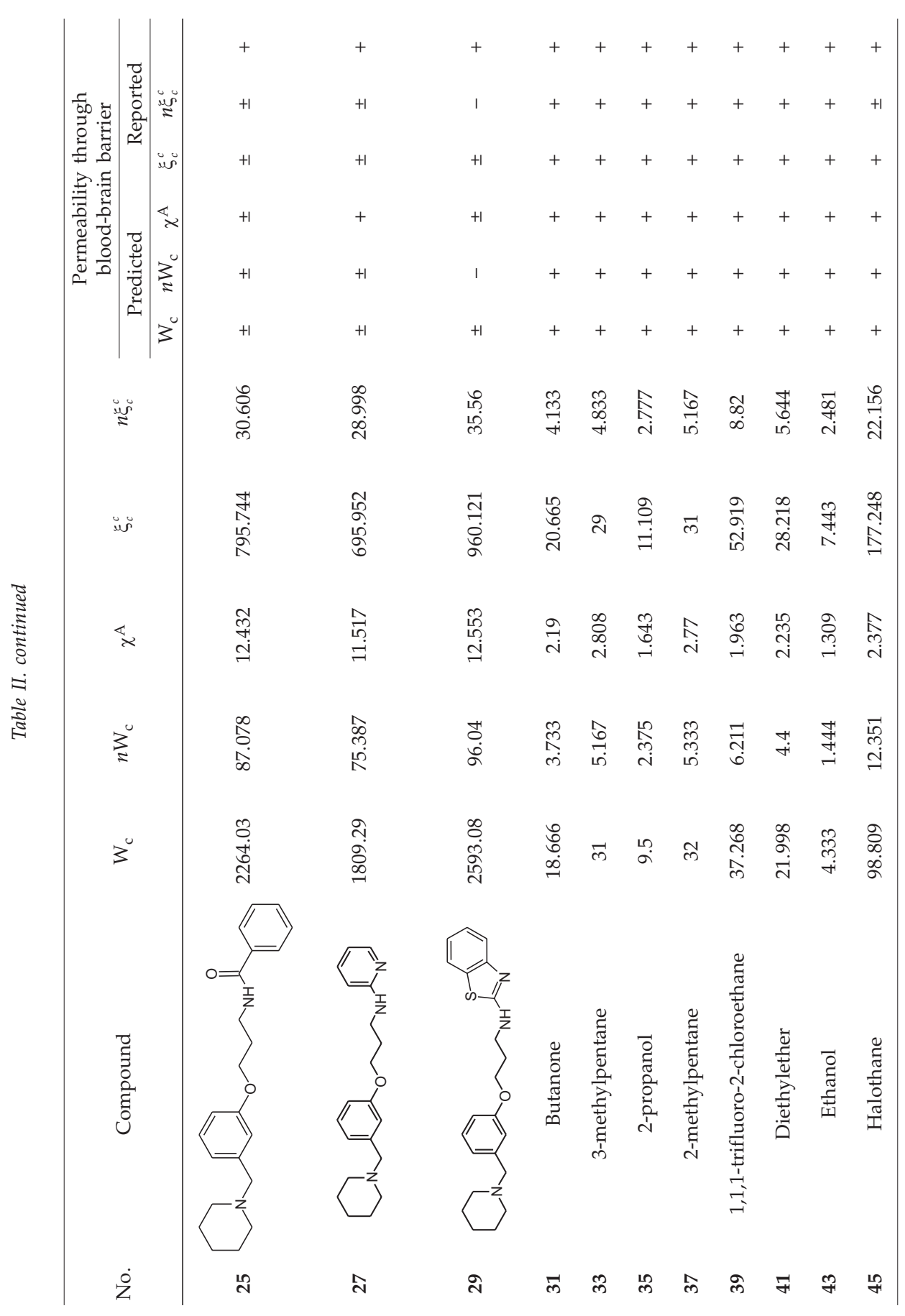


H. Dureja and A. K. Madan: Validation of topochemical models for the prediction of permeability through the blood-brain barrier, Acta Pharm. 57 (2007) 451-467.

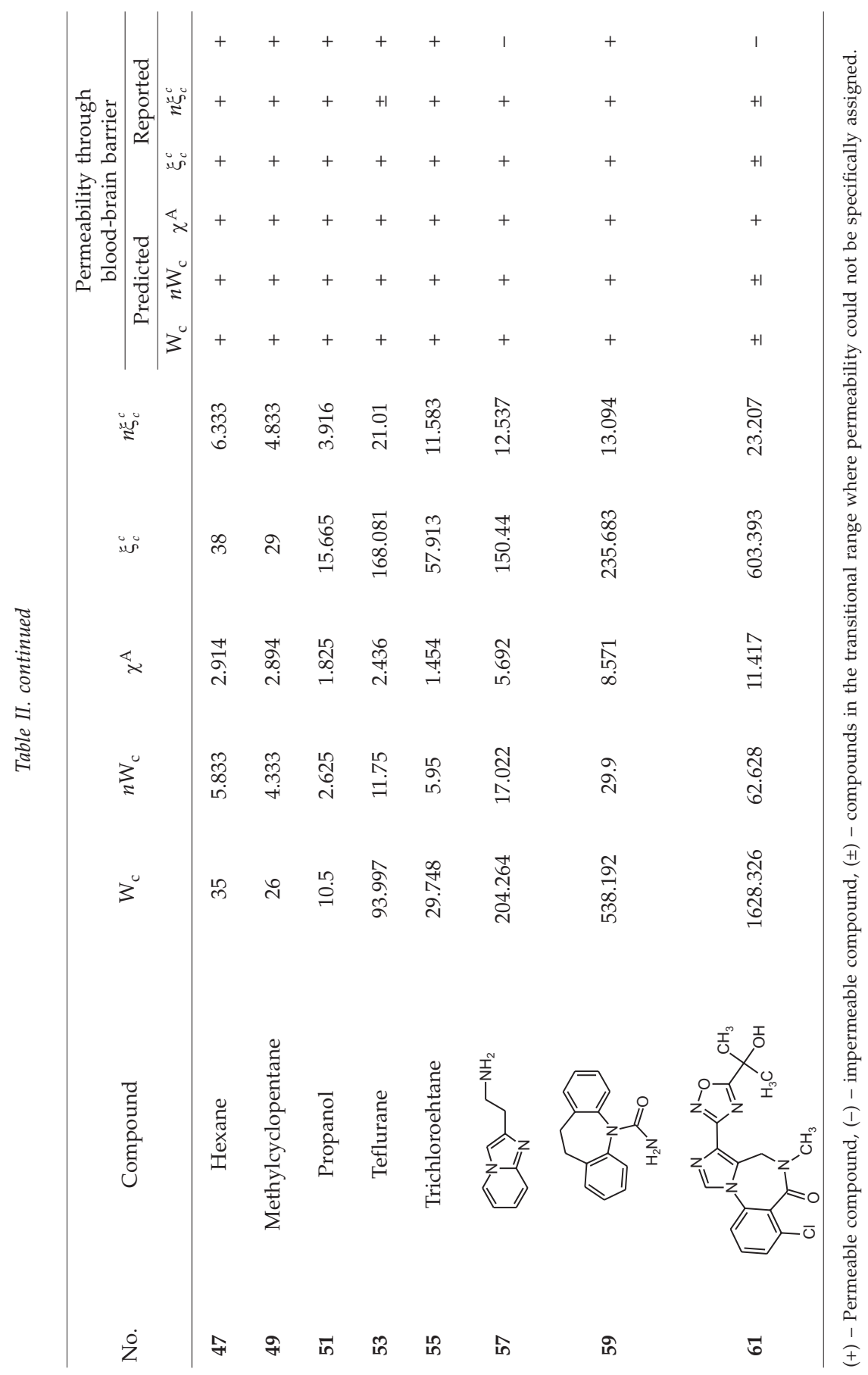


H. Dureja and A. K. Madan: Validation of topochemical models for the prediction of permeability through the blood-brain barrier, Acta Pharm. 57 (2007) 451-467.

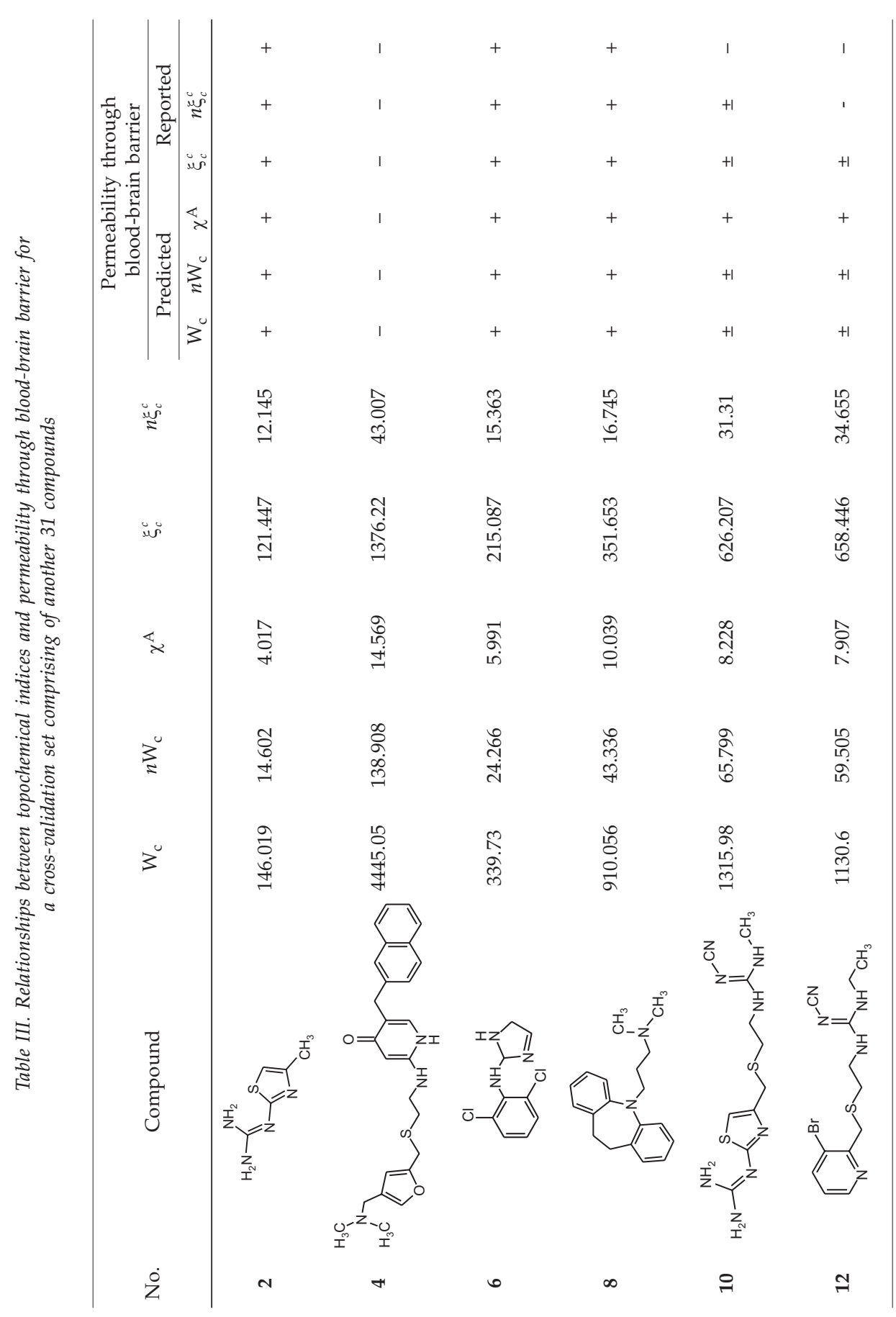


H. Dureja and A. K. Madan: Validation of topochemical models for the prediction of permeability through the blood-brain barrier, Acta Pharm. 57 (2007) 451-467.

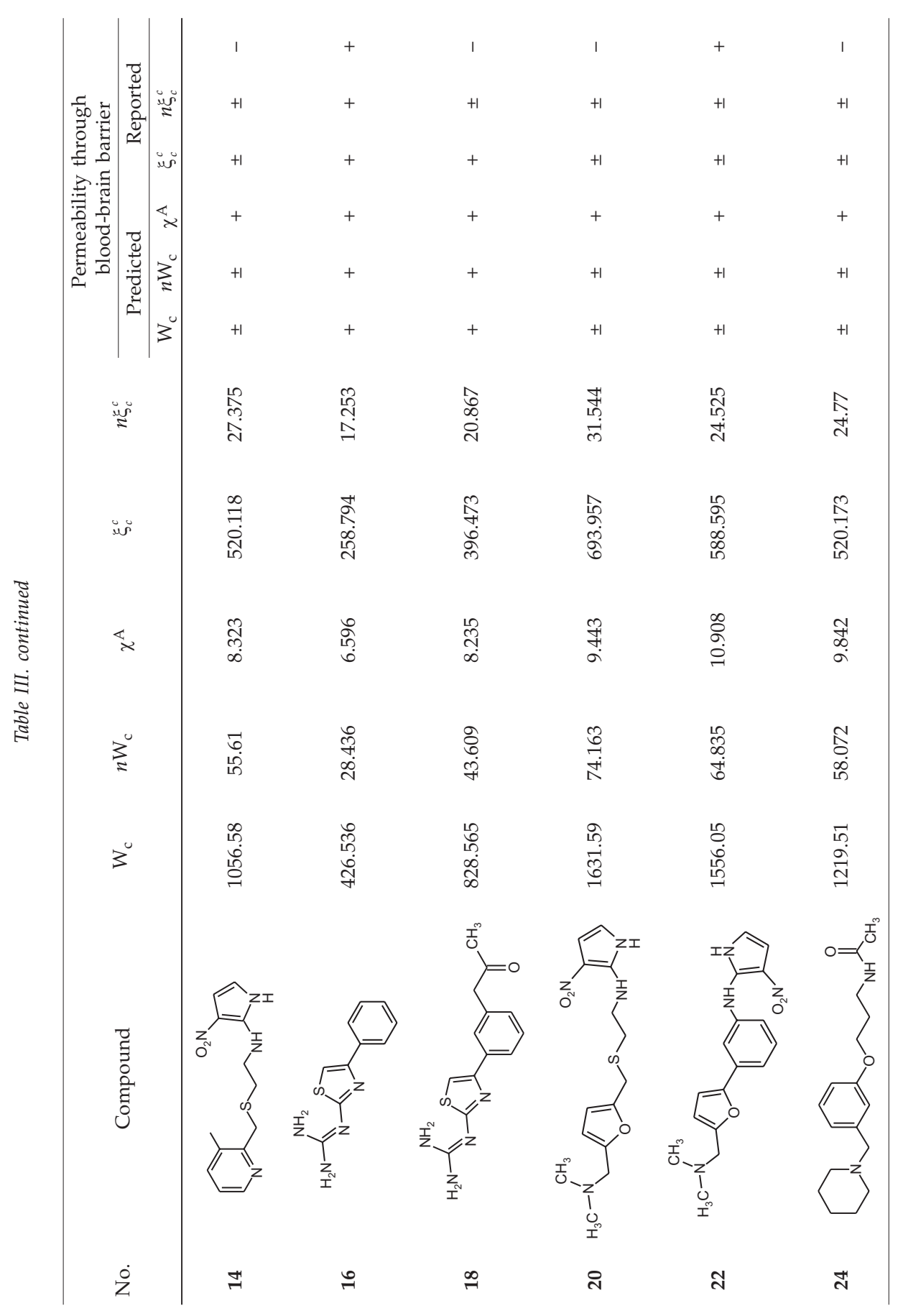


H. Dureja and A. K. Madan: Validation of topochemical models for the prediction of permeability through the blood-brain barrier, Acta Pharm. 57 (2007) 451-467.

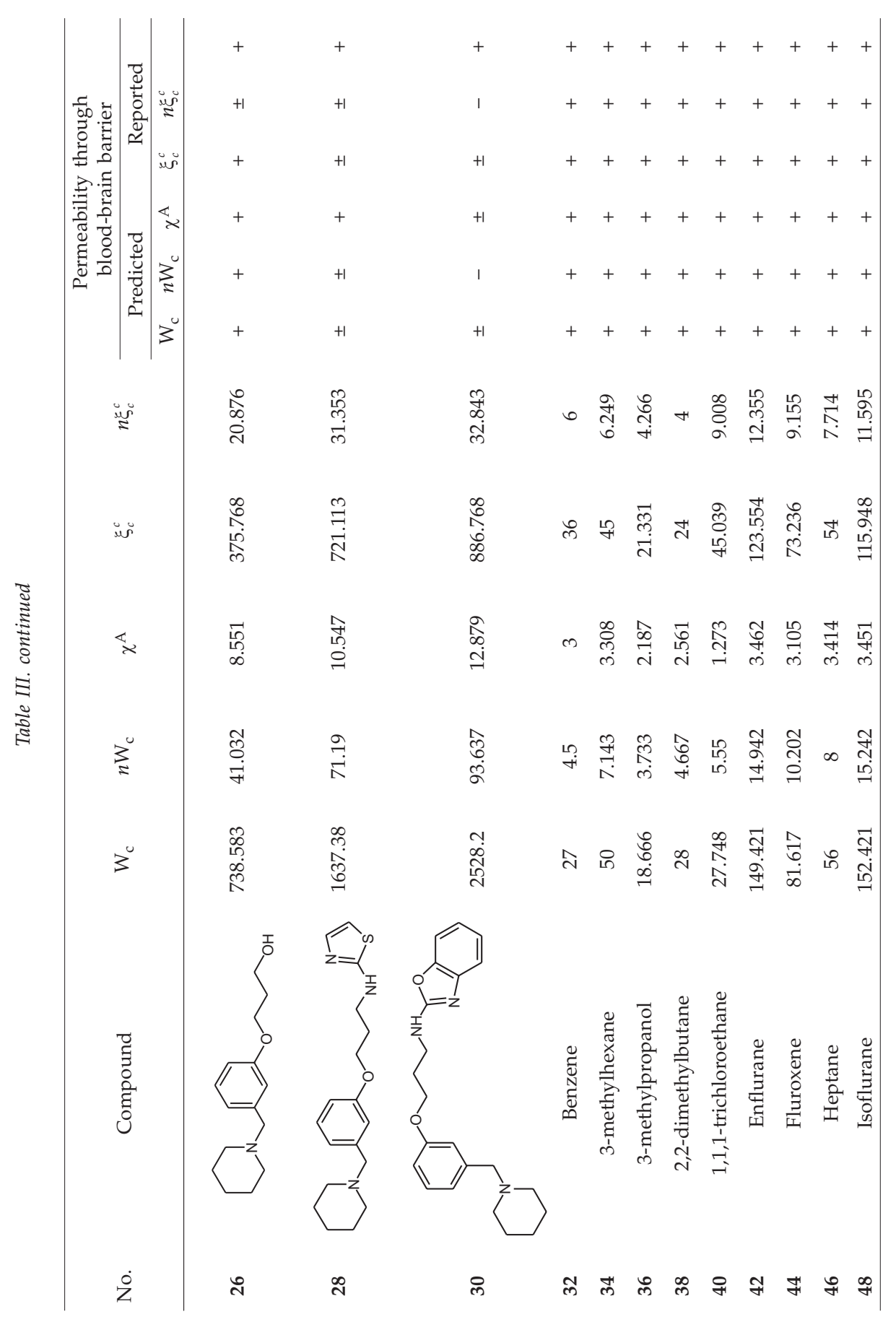


H. Dureja and A. K. Madan: Validation of topochemical models for the prediction of permeability through the blood-brain barrier, Acta Pharm. 57 (2007) 451-467.

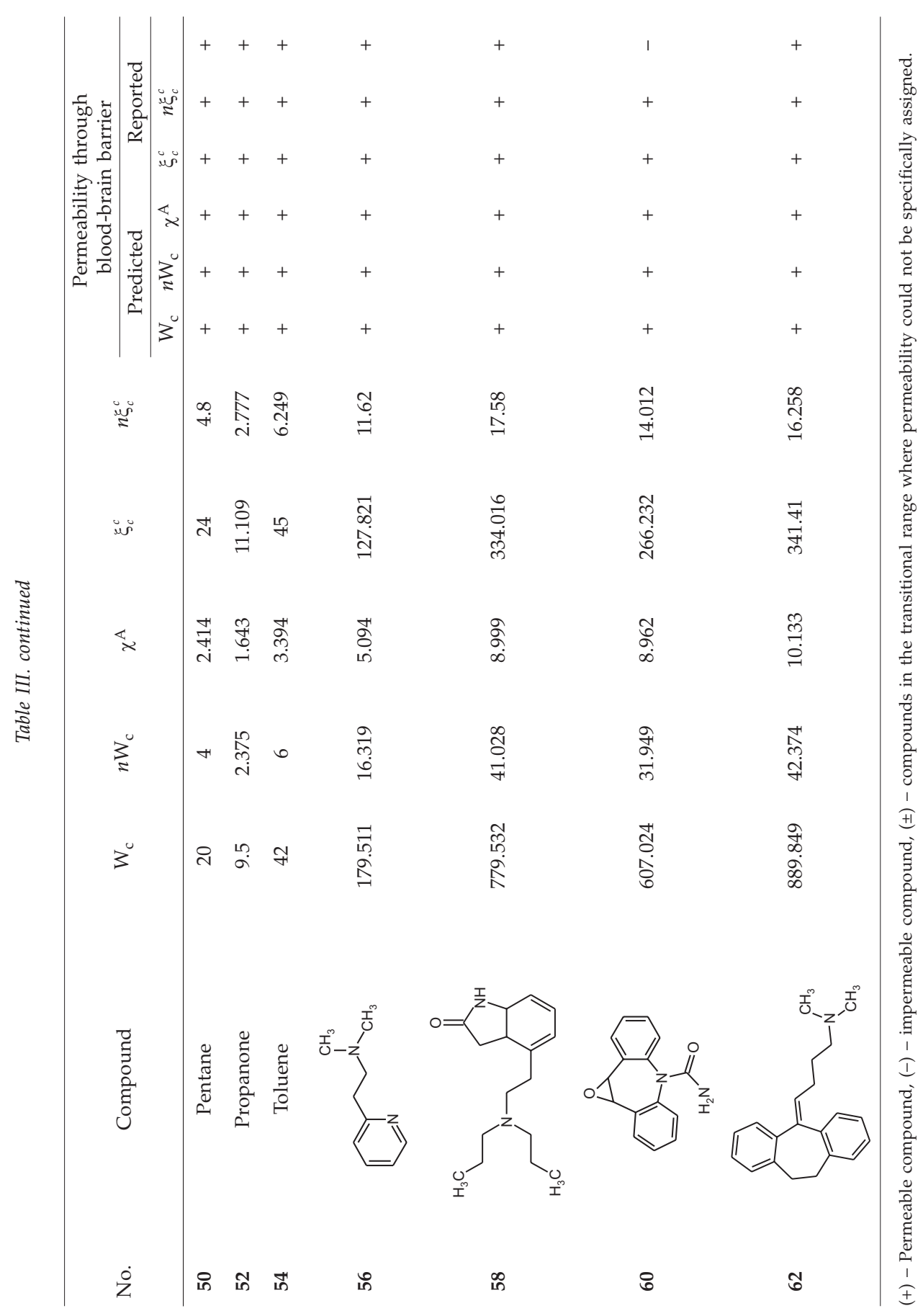


ous researchers including Iyer et al. (22) and Abraham et al. (23) had reported that compounds with $\log \mathrm{BB}$ values of $>0.3$ are readily permeated into the brain whereas compounds with values $<-1$ are poorly permeated into the brain. The cut-off value consi- dered for the present study was the average value of the ranges reported by earlier researchers $(22,23)$. Accuracy of prediction of permeable and impermeable ranges as well as the overall degree of prediction of the validated model were also calculated. A similar procedure was followed for the molecular connectivity topochemical index and the eccentric connectivity topochemical index/normalized eccentric connectivity topochemical index.

The aforementioned procedure was similarly followed during cross-validation of the second set of 31 compounds. The results are summarized in Tables II and III.

\section{RESULTS AND DISCUSSION}

Among the pharmacokinetics issues in the design of new drugs, prediction of the BBB permeability is a crucial factor (24). The relationship of topochemical models based on Wiener's topochemical index, molecular connectivity topochemical index and eccentric connectivity topochemical index with permeability through BBB was evaluated for prediction of permeability through the blood-brain barrier.

All the 62 compounds reported by Iyer et al. (22) were employed for validation study of topochemical models. These compounds were divided equally into two different groups to constitute validation and cross-validation sets. Compounds having odd serial numbers were designated as validation set while those having even numbers were categorized as cross-validation set.

The accuracy of prediction for the test set and for the cross-validation set are shown in Table IV. The methodology used in the present study relates to validation of topochemical models. These models have high potential for providing permeable compounds through exploitation of permeable ranges in the models derived from topochemical indices. These models are unique and differ widely from conventional QSAR models. Both systems of modeling have their advantages and limitations. In the present case, the modeling system adopted has the distinct advantage of identification of narrow permeable ranges, which may be erroneously skipped during routine regression analysis in conventional QSAR modeling. Since the ultimate goal is to provide permeable compounds, these permeability ranges can play a vital role in providing permeable compounds (14).

Retrofit analyses of the data (Tables I to IV) for validation and cross-validation sets reveal that the compounds were classified either as permeable or impermeable using the aforementioned models. A transitional range between permeable and impermeable ranges is ideal because it simply reveals the gradual change in permeability from the permeable range to an impermeable range. The overall accuracy of prediction during validation was found to vary from 70 to $80 \%$ (Table IV). However, the overall accuracy of prediction during cross-validation was found to be from 77 to $91 \%$ (Table IV). Four out of five models revealed overall accuracy of prediction $>87 \%$ during cross-validation.

Investigations on the use of topochemical indices on a test set comprising structurally and chemically diverse molecules have led to successful validation of topochemical 
models, which are highly beneficial for prediction of permeability through the blood-brain barrier. The overall accuracy of prediction of models for the validation set varied from a minimum of $70 \%$ for a model based on the molecular connectivity topochemical index to a maximum of $80 \%$ in case of models based upon Wiener's topochemical index and eccentric connectivity topochemical index. Surprisingly, these topochemical models also confirm the high prediction potential during cross-validation from a minimum of $77 \%$ for a model based on molecular connectivity topochemical index to a maximum of $91 \%$ in case of models based upon Wiener's topochemical index, eccentric connectivity topochemical index and normalized eccentric connectivity topochemical index. The results clearly reveal that the aforementioned topochemical models bear high predictability and can be utilized for permeability prediction of drugs and drug-like molecules.

\section{CONCLUSIONS}

Models derived from the topochemical indices can be used for fast screening of virtual libraries having millions of molecules and providing potent therapeutic agents with high permeability through the blood-brain barrier.

\section{REFERENCES}

1. K. Rose, L. H. Hall and L. B. Kier, Modeling blood-brain barrier partitioning using the electrotopological state, J. Chem. Inf. Comput. Sci. 42 (2002) 651-666; DOI: 10.121/ci010127n.

2. D. E. Clark, Rapid calculation of polar molecular surface and its application to the prediction of transport phenomena. 2. Prediction of blood-brain barrier penetration, J. Pharm. Sci. 88 (1999) 815-821; DOI:10.1021/js980402t.

3. J. M. Luco, Prediction of the brain-blood distribution of a large set of drugs from structurally derived descriptors using partial least-square (PLS) modeling, J. Chem. Inf. Comput. Sci. 39 (1999) 396-404; DOI: 10.121/ci980411n.

4. G. M. Keseru and L. Molnar, High-throughput prediction of blood-brain partitioning: A thermodynamic approach, J. Chem. Inf. Comput. Sci. 41 (2001) 120-128; DOI: 10.1021/ci000043z.

5. X.-L. Ma, C. Chen and J. Yang, Predictive model of blood-brain barrier penetration of organic compounds, Acta Pharmacol. Sin. 26 (2005) 500-512; DOI: 10.1111/j.1745-7254.2005.00068.x.

6. R. Liu, H. Sun and S.-S. So, Development of quantitative structure-property relationship models for early ADME evaluation in drug discovery. 2. Blood-brain barrier penetration, J. Chem. Inf. Comput. Sci. 41 (2001) 1623-1632; DOI: 10.1021/ci010290i.

7. J. Kelder, P. D. J. Grootenhuis, D. M. Bayada, L. P. C. Delbressine and J.-P. Ploemen, Polar molecular surface as a dominating determinant for oral absorption and brain penetration of drugs, Pharm. Res. 16 (1999) 1514-1519; DOI: 10.1023/A:1015040217741.

8. N. J. Abbott, L. Rönnbäck and E. Hansson, Astrocyte - endothelial interactions at the bloodbrain barrier, Nat. Rev. Neurosci. 7 (2006) 41-53; DOI: 10.1038/nrn1824.

9. F. Lombardo, J. F. Blake and W. J. Curatolo, Computation of brain-blood partitioning of organic solutes via free energy calculations, J. Med. Chem. 39 (1996) 4750-4755; DOI: 10.1021/jm960163r. 
10. P. Crivori, G. Cruciani, P.-A. Carrupt and B. Testa, Predicting blood-brain barrier permeation using three-dimensional molecular structure, J. Med. Chem. 43 (2000) 2204-2216; DOI: 10.1021/ jm990968.

11. R. Kunal, Topological descriptors in drug design and modeling studies, Mol. Div. 8 (2004) 321323; DOI: 10.1023/B:MODI.0000047519.35591.b7.

12. S. C. Basak, S. Bertelsen and G. Grunwald, Application of graph theoretical parameters in quantifying molecular similarity and structure-activity studies, J. Chem. Inf. Comput. Sci. 34 (1994) 270-276; DOI: 10.1021/ci00018a007.

13. B. D. Gute and S. C. Basak, Predicting acute toxicity $\left(\mathrm{LC}_{50}\right)$ of benzene derivatives using theoretical molecular descriptors: A hierarchical QSAR approach, SAR QSAR Environ. Res. 7 (1997) 117-131; DOI: 10.1080/10629369708039127.

14. H. Dureja and A. K. Madan, Topochemical models for prediction of permeability through blood-brain barrier, Int. J. Pharm. 323 (2006) 27-33; DOI: 10.1016/j/ijpharm.2006.05.042.

15. S. Bajaj, S. S. Sambi and A. K. Madan, Predicting anti-HIV activity of phenethylthiazolethiourea (PETT) analogs: computational approach using Wiener's topochemical index, J. Mol. Struct. (THEOCHEM) 684 (2004) 197-203; DOI: 10.1016/j.theochem.2004.01.052.

16. H. Wiener, Correlation of heat of isomerization and difference in heat of vaporization of isomers among paraffin hydrocarbons, J. Am. Chem. Soc. 69 (1947) 2636-2638; DOI: 10.1021/ja01203a022.

17. A. Goel and A. K. Madan, Structure-activity study on anti-inflammatory pyrazole carboxylic acid hydrazide analogs using molecular connectivity indices, J. Chem. Inf. Comput. Sci. 35 (1995) 510-514; DOI: 10.1021/ci00025a019.

18. H. Dureja and A. K. Madan, Topochemical models for prediction of cyclin-dependent kinase 2 inhibitory activity of indole-2-ones, J. Mol. Mod. 11 (2005) 525-531; DOI: 10.1007/s00894-0050276-3.

19. M. Randic, On characterization of molecular branching, J. Am. Chem. Soc. 97 (1975) 6609-6615; DOI: $10.1021 /$ ja00856a001.

20. V. Kumar, S. Sardana and A. K. Madan, Predicting anti-HIV activity of 2,3-diaryl-1,3-thiazolidin-4-ones: computational approach using reformed eccentric connectivity index, J. Mol. Mod. 10 (2004) 399-407; DOI: 10.1007/s00894-004-0215-8.

21. V. Sharma, R. Goswami and A. K. Madan, Eccentric connectivity index: a novel highly discriminating topological descriptor for structure property and structure activity studies, J. Chem. Inf. Comput. Sci. 37 (1997) 273-282; DOI: 10.1021/ci960079h.

22. M. Iyer, R. Mishra, Y. Han and A. J. Hopfinger, Predicting blood-brain barrier partitioning of organic molecules using membrane-interaction QSAR analysis, Pharm. Res. 19 (2002) 1611-1621; DOI: $10.1023 /$ A:1020792909928.

23. M. H. Abraham, K. Takacs-Novak and R. C. Mitchell, On the partition of ampholytes: Application to blood-brain distribution, J. Pharm. Sci. 86 (1997) 310-315; DOI: 10.1021/js960328j.

24. M. C. Hutter, Prediction of blood-brain barrier permeation using quantum chemically derived information, J. Computer-Aided Mol. Des. 17 (2003) 415-433; DOI: 10.1023/A:1027359714663. 


\section{$S A Z ̌ E T A K$}

\section{Validacija topokemijskih modela za predviđanje permeabilnosti kroz krvno-moždanu barijeru}

HARISH DUREJA i ANIL KUMAR MADAN

U ovom su radu validirani i unakrsno validirani nedavno objavljeni topokemijski modeli za permeabilnost kroz krvno-moždanu barijeru. Predviđanje prolaska kroz krvno-moždanu barijeru strukturno i kemijski različitih molekula provedeno je na pet modela koji se temelje na tri topološka indeksa, Wienerovom topološkom indeksu, topološkom indeksu molekularne povezanosti i topološkom indeksu ekscentrične povezanosti. Ukupno 62 spoja podijeljena su u dva seta koji su sadržavali 31 spoj. Jedan set upotrebljen je za validaciju, a drugi za unakrsnu validaciju. Vrijednosti svih triju topoloških indeksa u početnom setu i u normaliziranom setu su računate pomoću kompjutorskog programa. Rezultati su analizirani i svakom spoju je pridružena teorijska vrijednost permeabilnosti, koja je zatim uspoređivana s objavljenim eksperimentalnim podacima za permeabilnost kroz krvno-moždanu barijeru. Točnost predviđanja bila je između 70 i $80 \%$. Isti postupak je proveden za unakrsno validacijski set, a točnost je bila iznenađujuće velika (77-91\%), što ukazuje da se upotrebljeni topokemijski modeli mogu upotrijebiti za predviđanje permeabilnost kroz krvno-moždanu barijeru.

Ključne riječi: topokemijski indeksi, Wienerov topološki indeks, topološki indeks molekularne povezanosti, topološki indeks ekscentrične povezanosti, permeabilnost, krvno-moždana barijera

Faculty of Pharmaceutical Sciences, M. D. University, Rohtak-124001, India 